\title{
Macroscopic dynamic response of mechanical systems involving composites and effect of inner structure on damping properties
}

\author{
Makroskopowa odpowiedź dynamiczna układów mechanicznych \\ z udziałem kompozytów \\ oraz wpływ ich struktury wewnętrznej na właściwości tłumiące
}

\section{ZUZANA MURČINKOVÁ*}

The paper deals with relation between inner structure of the machine and the composite material used in it and macroscopic dynamic response. It presents the experimental results of testing the relation between inner composite material structure and damping properties presented by logarithmic decrement quantity. Moreover, the paper provides the case study of application the composite material layered structure to the flexographic printing machine and results of that applications presented by printing speed.

KEYWORDS: inner structure, damping, dynamic response, carbon fiber, composite cylinder, shaft accuracy, vibration

Wartykule omówiono zależność między wewnętrzną budową maszyny $i$ wykorzystanego w niej materiału kompozytowego a makroskopową odpowiedzią dynamiczną układu. Przedstawiono wyniki badań zależności między wewnętrzną strukturą materiału kompozytowego a właściwościami tłumiącymi wyrażonymi przez logarytmiczny dekrement tłumienia. Ponadto zaprezentowano studium przypadku - zastosowanie kompozytu warstwowego w konstrukcji drukarki fleksograficznej oraz wpływ tego rozwiązana na uzyskiwaną prędkość druku.

SŁOWA KLUCZOWE: struktura wewnętrzna, tłumienie, odpowiedź dynamiczna, włókno węglowe, cylinder kompozytowy, dokładność wału, drgania

\section{Introduction}

Known traditional materials are at their limits when using them in conditions of ever-increasing requirements to keep developing. Advanced and new materials may replace them. However, mechanical properties of such materials, often anisotropic, are complex. The present research tries to overcome difficulties of designing, simulation, and calculations, optimization, manufacturing and joining. The challenge is to tailor such materials according to specific requirements.

Composites are known by their outstanding mechanical properties, e.g. toughening effect of mechanical and thermal fields, also electric, magnetic fields. Static characteristics are of the same importance as dynamic ones. The experimental testing is supported by damping modeling using a finite element analysis evaluating different energies dissipated in material directions of layers [1,2]. It is stated that the damping of composite materials can be several orders of magnitude higher than that of traditional engineering materials, making them appealing also for components undergoing dynamic loading.

The general mathematical model of dynamic system (of $n$ degrees of freedom) is expressed by $n$ differential equation system in form:
DOI: https://doi.org/10.17814/mechanik.2019.4.38

$$
\mathbf{M} \ddot{\mathbf{q}}(t)+\mathbf{C} \dot{\mathbf{q}}(t)+\mathbf{K q}(t)=\mathbf{F}(t)
$$

where: $\mathbf{M}, \mathbf{C}, \mathbf{K}-$ matrix of weight, damping and stiffness of mechanical system of $n \times n$ dimension; $\mathbf{F}$ - vector of load (excitation forces); q, $\dot{\mathbf{q}}, \ddot{\mathbf{q}}-$ vector of displacements (linear and angular), velocities and accelerations.

The macroscopic dynamic response of structures described by the equation above is important in engineering applications. Generally, it is supposed that the individual components in machine tools, the component joints and functional modules are made from homogenous and isotropic materials of certain material damping. As for the dynamic response, the best combination of structural material properties would be high damping along with high stiffness and low weight, which is related to the equation. Such materials are not among common natural materials.

Composite materials, consisting of different materials, considerably change material damping, energy dissipation, and the vibration and shock wave propagation. The factors which allow to improve and control the energy dissipation and transfer the load and mechanical waves are: naturally, the individual properties of constituents, but also the microscopic material structure arrangement and interface fibre-matrix $[3,4]$. The mentioned factors are subject of present research in the mechanics of composite materials.

We focused on the investigation of dynamic properties by measurement of logarithmic decrement of free damped vibrations (some of the results are provided in section "Improved composite material damping"). In section "Problem description", the case study based on utilizing the composite material damping is provided with quantification of results regarding benefits of the composite material application in a dynamic mechanical system.

\section{Improved composite material damping}

The measurement is based on free damped vibration decay response. The measuring stand with the clamped sample is shown in Fig. $1 a$. The samples are with one fixed side and the vibrations are excited by the bump of a steel ball, Fig. $1 b$.

The samples consist of three layers of carbon fibre twill fabric in the epoxy resin matrix. First and second sample (denoted C\#\#\# and CXXX) have all layers with the same orientation, i.e. the warp fibres are parallel to sample edges and diagonal, respectively (see: Table I). The layup of

\footnotetext{
* Zuzana Murčinková (zuzana.murcinkova@tuke.sk), https://orcid.org/0000-0003-0306-7975 - Faculty of Manufacturing Technologies with seat in Prešov, Technical University of Košice, Bayerova 1, 08001 Prešov, Slovak Republic
} 


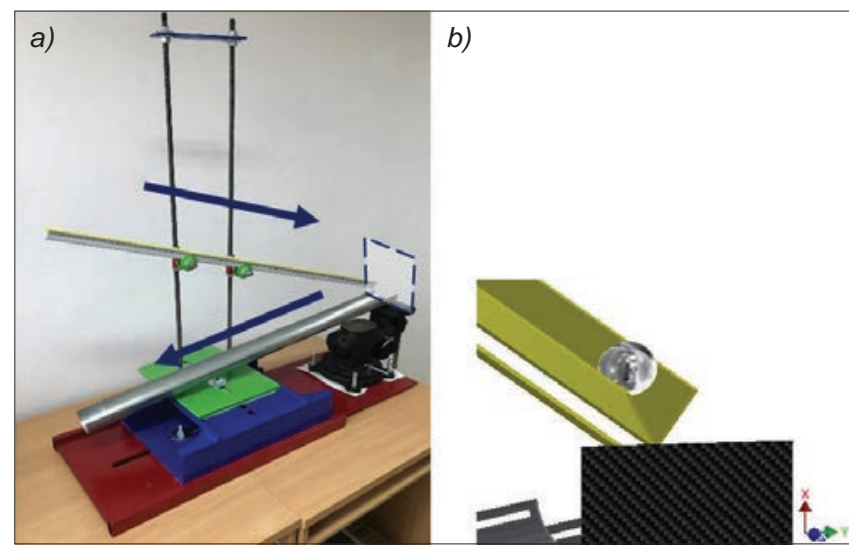

Fig. 1. Measuring stand (a), bumping ball (b)

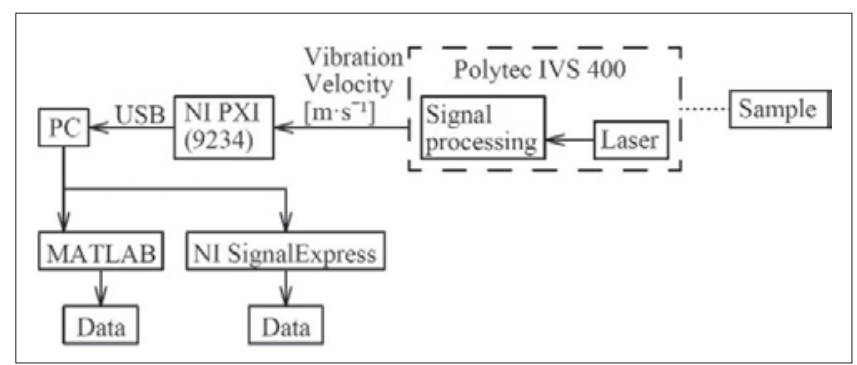

Fig. 2. Measurement set-up

TABLE I. Material configurations and their logarithmic decrement

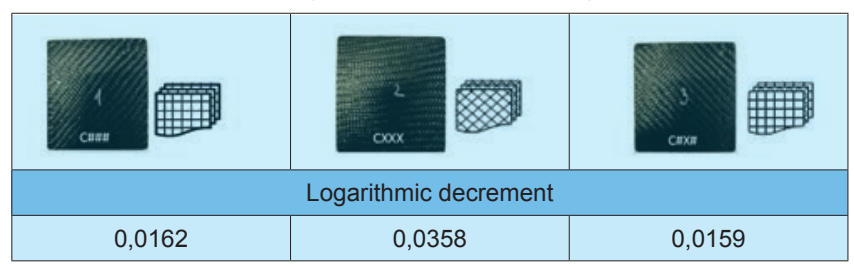

the third sample is \#X\# (see: Table I). The twill weave distorts visibility of the real orientation of the warp and weft, hence the schema is added.

The velocity of displacement (vibrations) of the middle point of the opposite free side is scanned by contactless laser vibrometer Polytec IVS 400. The signal is processed into the output data in the form of time decaying curves. The measurement set-up is shown in Fig. 2.

The logarithmic decrement differs in relation to the material orientation. The larger the logarithmic decrement is, the less the number of the decaying cycles is required to reduce the amplitude. In the case of carbon-fibre laminates, the logarithmic decrement may be lower (up to about 33\% for layups \#\#\# and \#X\#) or higher (up to 49\% for layup XXX) compared with conventional material, as steel, and depends on the material configuration. In the case of layup \#X\#, the different middle layer does not influence the logarithmic decrement significantly comparing with layup \#\#\#.

It may be noticed that the material configuration influences the damping properties. We confirm that macroscale dynamic properties (mainly material damping) of fibre composites can be modified by microscale inner structure.

\section{Problem description}

Fig. 3 shows the schema of the printing section of flexographic printing machine. The printed flexible films are intended for packaging in the food and chemical industry. The flexible thin plastic (film) passes individual printing

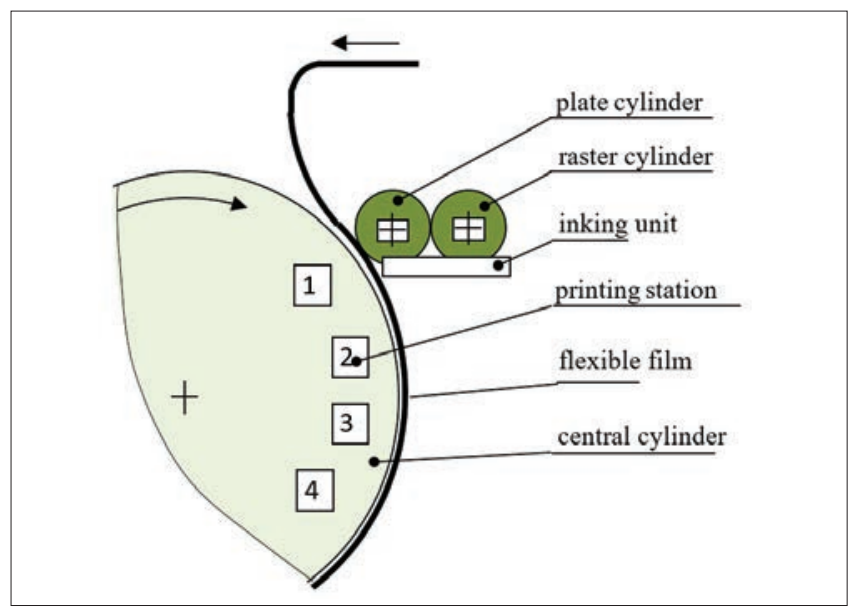

Fig. 3. Schema of printing section

stations and it enters the drying section. Each printing station involves plate and anilox (raster) cylinders with inking unit of certain colour. The raster cylinder has small holes (cells) or grooves which are filed by colour ink while it rotates. The printing areas of printing plate pattern are higher than the non-printing area. The ink is applied to relief of plate. The profile of plate is imprinted on flexible film that is passing to another printing station with another plate and colour.

The main requirement is higher printing speed keeping the printing quality. The repeated contact of the plate and external central cylindrical surface influences the quality.

The measurements were made in cooperation with Technical Diagnostics, Itd. Acceleration Enveloping (Fig. 4) detects the repeating vibration signals in high frequencies range. Acceleration Enveloping confirms that repeating impact is caused by the straight edge of the pattern at plate cylinder into the central cylinder. While vibration is being damped, the area of the flexible film is without colour. If the higher printing speed is used, the impact force is higher, the time of damping is longer and the quality of printing is worse. Such printing conditions bring the areas on film without colour and/or individual colours are overlapped. There are more or less suitable reliefs of printing plates in term of vibrations. The printing speed is influenced by unwanted straight rising edges. Moreover, the magnitude of vibrations is influenced by the material of plate on the plate cylinder.

Analyses of dynamic processes of flexographic printing machine result in a suggestion of two steps of a solution in order to achieve the most quality of printing and the most productivity:

- $1^{\text {st }}$ step: printing sections arrangement,

- $2^{\text {nd }}$ step: use of composite cores and/or cases of plate cylinders.

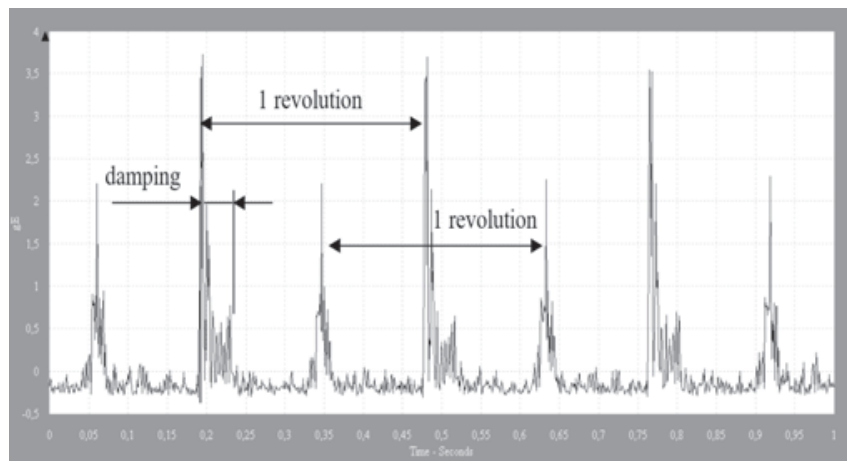

Fig. 4. Time record (1 s) of Acceleration Enveloping 


\section{Printing section arrangement}

To decrease the vibration, the following arrangement was made on the flexographic printing machine:

- exchange of bearing mounting at the operator and drive side,

- the setting of radial clearance of main needle bearings by selection of the shaft tolerance,

- control of radial run out of cylinders surface and tolerance of concentricity compared with axes of shaft bearing cylinders.

The correct operation of flexographic printing machines is strongly influenced by the radial clearance of needle bearing. Standard needle bearings are produced with normal radial clearance. The optimal function of needle bearing is guaranteed by the producer in case of recommended radial clearance in range of $30 \div 50 \mu \mathrm{m}$.

The dimensional and geometrical accuracy of the shaft surface on which the bearing is mounted have a crucial impact on the resulting radial clearance and vibrations. The surface wave usually results from disturbances in the manufacturing process, such as vibrations between the workpiece and the grinding wheel [5]. Moreover, the surface irregularity resulting from for example the guideway errors, errors of rotary elements, by thermal expansion of elements or by fixing the workpiece $[5,6]$. The bearing inner race is thin-walled and thus after pressing the inner race on the shaft, the dimension after pressing and the final clearances are achieved by shaft tolerance size and accuracy of shaft geometry up to $90 \%$ [7]. After mounting, the bearing working clearance is smaller and the shape of the shaft surface is "copied" on the shape of the inner bearing race.

TABLE II. Measuring, printing station 8, printing assortment $X$

\begin{tabular}{|c|c|c|c|c|c|c|c|}
\hline \multicolumn{2}{|c|}{} & \multicolumn{2}{|c|}{ Velocity $\left[\mathrm{mm} \cdot \mathrm{s}^{-1}\right]$} & \multicolumn{2}{c|}{ Acceleration [g] } & \multicolumn{2}{c|}{ Time Acc [g] } \\
\hline \multicolumn{2}{|c|}{ Printing station 8 } & Before & After & Before & After & Before & After \\
\hline \multirow{2}{*}{ OS } & $\leftrightarrow$ & 5,84 & 1,32 & 0,34 & 0,10 & 2,8 & 1,4 \\
\cline { 2 - 9 } & $\uparrow$ & 1,78 & 1,00 & 0,15 & 0,10 & 2,0 & 1,2 \\
\hline \multicolumn{2}{|c|}{ Alarm } & Danger & $\checkmark$ & Danger & $\checkmark$ & Danger & $\checkmark$ \\
\hline \multirow{2}{*}{ DS } & $\leftrightarrow$ & 6,94 & 1,04 & 0,28 & 0,08 & 2,2 & 0,8 \\
\cline { 2 - 9 } & $\uparrow$ & 1,56 & 0,59 & 0,10 & 0,09 & 1,8 & 1,0 \\
\hline \multicolumn{2}{|c|}{ Alarm } & Danger & $\checkmark$ & Danger & $\checkmark$ & Danger & $\checkmark$ \\
\hline
\end{tabular}

Note: OS - operator side, DS - drive side, $\leftrightarrow$ horizontal direction, $\uparrow$ vertical direction

The estimation of the state of measured machine elements is according to standard STN ISO 10816-3: Measuring of vibrations. The recommended limits of Warning and Danger alarms of summing vibrations are given in mentioned standard (Table II). Moreover, Table II introduces the measured vibrations on selected printing station 8 at the operator side (OS) and drive side (DS) before the arrangement and the measured values at the same locations after the arrangement, e.g. after changing the bearings, setting the radial clearance and control of rotational accuracy of cylinders.

Fig. 5 shows the fast Fourier transformation (FFT) spectrums of printing station 8 before and after the arrangement.

The measurements were made for each printing station $1-8$. After the arrangements, the strong decreasing of vibrations and decreasing of dynamic excitation of printing stations appeared that result in increasing the quality of printing.

\section{Application of composite material}

Another stage of the vibration problem decrease can be solved through the use of dynamic characteristics of composite materials. The special printing plate cylinders (Fig. 6) based on composite materials were applied. Such an approach requires larger expenses for investment comparing with the previous approach.

In general, the printing cylinders consist of core and casing (Fig. 6). Different material combinations can be used, i.e. either steel core and composite casing or composite core and composite casing. The composite casings form the multi-layered structure, the composite cores are made of fibre composites (Fig. 6).

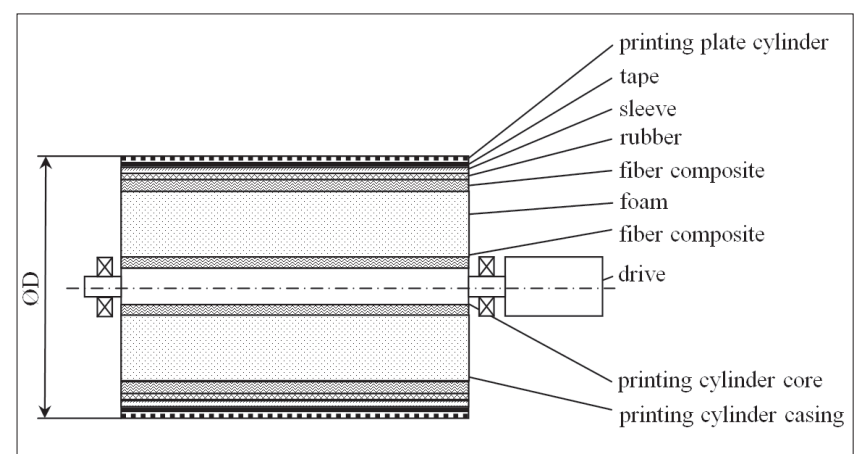

Fig. 6. Printing cylinder

One of many advantages of the composite printing cylinders is their minimal deflection regarding the high cylinder stiffness. The Young's modulus of composite cylinders is about $400 \mathrm{GPa}$. Furthermore, composite cylinders are lightweight and need less energy to drive and thus provide a source of energy saving. They are called superlight comparing with steel cylinders.

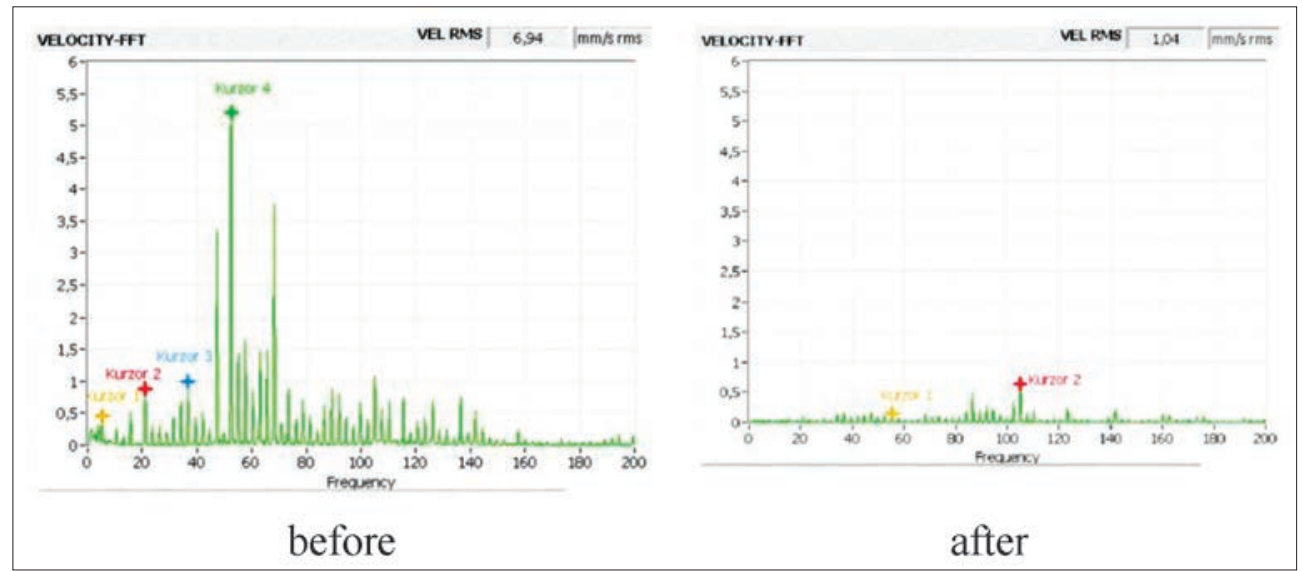

Fig. 5. FFT spectrums - printing station 8 , drive side, horizontal direction 
Various producers of composite printing cylinders differentiate by inner structure and material of the printing cylinder. The used composite printing cylinders in the presented application consist of winded high/super-high module carbon fibres. There are also producers of the cylinders of specific structure involving the aluminium profile with a filling of fibres oriented in one direction that increases the stiffening effect. The research and development in the field of advanced applications of composite materials are in progress.

The printing speed of steel core cylinders and ordinary/ /original casing (ordinary printing cylinder in Fig. 7) was $150 \mathrm{~m} / \mathrm{min}$. The combination of steel core and composite printing cylinders casing allowed $170 \div 180 \mathrm{~m} / \mathrm{min}$ of printing speed and both the printing cylinder composite core and casing achieved $220 \div 230 \mathrm{~m} / \mathrm{min}$. Application of nonconventional material provided $20 \%$ and $53 \%$ of increasing the printing speed keeping the quality. In present, the disadvantage is the price of the composite cylinder that is $100 \%$ higher compared to steel.

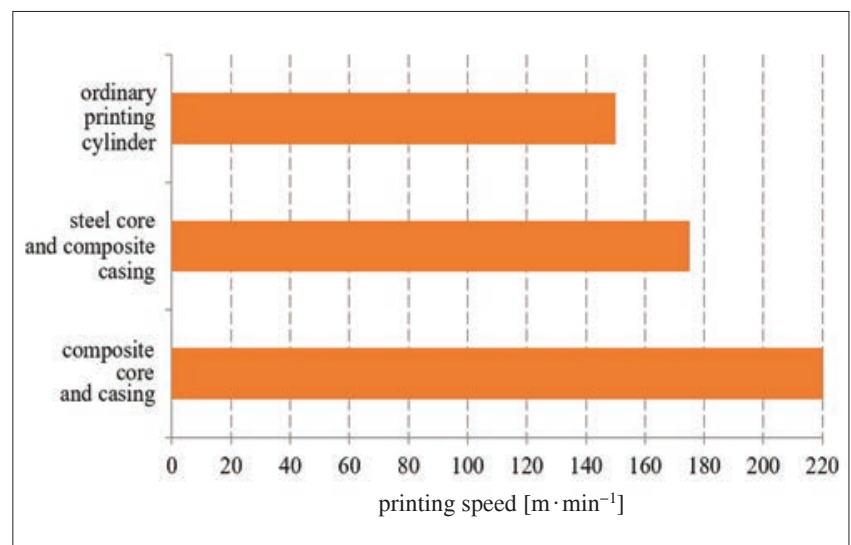

Fig. 7. Printing speed - results

\section{Discussion}

As for the dynamic response, the complex microstructure with fibres/particles causes very important effects. The decohesion and the reversing recohesion appear in the fibre-matrix interface, fibres ends and layer-layer interface. The mentioned effects are the source of material damping and thus mechanical energy absorption. The ability of absorption is increased by the addition of lubricating material, however, it makes the worse bonding on the fibre-matrix interface. The composite materials made without interlayer have high shear strength on the fibrematrix interface, but the low resistance on longitudinal cracks at the fibre-matrix interface.

The analyses of dynamic processes of flexographic printing production machines show two resources of improving the productivity keeping the quality: machine arrangement, i.e. off-line vibrodiagnostics control and improving the accuracy of mounting and of individual machine parts in component joints; and composite materials and structures application.

Firstly, the radial clearance and accuracy of shaft/cylinder have the main role in dynamic excitation resulting in unwanted vibrations of printing cylinder of flexographic printing machine as well as the complexity of the printed image and its relief and sequence of individual colours of printing positions. Secondly, the task of vibrations reduction is solved by the use of composite core and/or casing of printing cylinder with special composite material configuration and design that allow reducing the vibrations and improving the damping. The printing process is influenced also by other factors, e.g. properties of tint (viscosity), material properties of flexible films, control of printing pressure between the plate and central impression cylinder.

Despite the fact that new advanced flexographic printing machines involve diagnostics of printing quality monitoring, the important role in flexo-printing is know-how of the printer operator who is able to find the maximum printing speed keeping the appropriate quality involving all factors.

\section{Conclusions}

The experimental testing confirmed the impact of the inner material configuration on the macroscopic response. Comparing the conventional materials (steel, concrete, cast iron etc.) and the fibres/particles composites, the conventional materials are of low inner material friction that causes the low absorption of vibrations and waves. We suppose that the relatively large surface of interfaces of fibres and matrix contributes to better damping properties; despite the fact that fibres are stiff, the effects on the fibre-matrix interface are the source of fine damping and energy dissipation along with damping properties of the matrix. In the case of layered long-fibre composite materials, the layer-layer interface could improve their damping properties.

Based on the flexographic printing machine case study, we confirm the benefits of composite materials and direct relation between the inner machine structure and macroscopic dynamic behaviour. Moreover, the applications of composite material need an integrated approach to the problem. In the presented case, it was machine arrangement including mounting and accuracy of operating components with the application of composites.

\section{Acknowledgement}

The authors would like to thank the Agency of Ministry of Education, Science, Research and Sport of the Slovak Republic for supporting this research (grant VEGA 1/0910/17).

\section{REFERENCES}

[1] Rouf K., Denton N.L., French R.M. "Effect of fabric weaves on the dynamic response of two-dimensional woven fabric composites". Journal of Materials Science. 52, 17 (2017): 10581-10591. https://doi. org/10.1007/s10853-017-1183-6.

[2] El Mahi A., Assarar M., Sefrani Y., Berthelot J.M. "Damping analysis of orthotropic composite materials and laminates". Composites Part B: Engineering. 39, 7-8 (2008): 1069-1076. https://doi.org/10.1016/j. compositesb.2008.05.003

[3] Murčinková Z., Halapi M. "Analysis of the material configurations and influence on the dynamic response". MATEC Web of Conferences: Machine Modelling and Simulations 2017 (MMS 2017). 157 (2018): 05018. EDP Sciences. https://doi.org/10.1051/matecconf/201815705018.

[4] Murčinková Z., Halapi M. "Micro-mechanical response of continuous and discontinuous fiber composites with support of computational software". Int. J Innovative Sci., Eng. Technol. 3, 1 (2016): 300-304.

[5] Adamczak S., Makieła W., Stępień K. "Investigating advantages and disadvantages of the analysis of a geometrical surface structure with the use of Fourier and wavelet transform". Metrology and Measurement Systems. 17, 2 (2010): 233-244. 10.2478/v10178-010-0020-x.

[6] Vasilko K. "Teória a prax trieskového obrábania". Prešov: COFIN, 2009, 35-82.

[7] Murčinková Z., Baron P., Pollák M. "Study of the press fit bearing-shaft joint dimensional parameters by analytical and numerical approach". Advances in Materials Science and Engineering. 2018 (2018). https:// doi.org/10.1155/2018/2916068 